\title{
REVISED CHECKLIST OF SASKATCHEWAN BUTTERFLIES
}

RONALD R. HOOPER, Saskatchewan Museum of Natural History, Wascana Park, Regina, Saskatchewan. S4P 3V7

With the publishing of $A$ catalogue/ checklist of the butterflies of America north of Mexico it has become necessary to revise Saskatchewan's butterflies checklist, and update the scientific names. ${ }^{4}$ In the "Machaon" group of Swallowtails, I have used some of the changes that are suggested by Felix Sperling. ${ }^{7}$ For the genus Polygonia, I have followed the arrangement given by Scott. ${ }^{6}$ Other changes are identified in the text.

Wherever there are new species being dealt with that are not recorded in Butterflies of Saskatchewan, the basis for these new records is given. ${ }^{3}$ An asterisk $\left({ }^{*}\right)$ is placed in front of each new species. Abbreviations are used for directions (i.e., $\mathrm{n} .=$ north, s. = south, e. = east, $\mathrm{w} .=$ west $)$. In Butterflies of Saskatchewan, 135 species of butterflies were recorded for Saskatchewan in 1973.

The present list contains 144 species.

\section{HESPERIOIDEA}

HESPERIIDAE - SKIPPERS PYGINAE

SILVER-SPOTTED SKIPPER

- Epargyreus clarus (Cramer)

- s. Sask., n. to Wadena and Batoche.

NORTHERN CLOUDY WING - Thorybes pylades (Scudder)

- s. Sask., n. to Pelican Narrows and Otter Rapids.

DREAMY DUSKY WING - Erynnis icelus (Scudder and Burgess)

- throughout Sask.

SLEEPY DUSKY WING - Erynnis brizo (Boisduval and Leconte)

- Tantallon, Hazelcliffe and Round Lake (n. of Whitewood).
JUVENAL'S DUSKY WING - Erynnis juvenalis (Fabricius)

- Tantallon, Round Lake (n. of Whitewood), and Oxbow.

AFRANIUS DUSKY WING - Erynnis afranius (Lintner)

- s. Sask., n. to Yorkton, Punnichy and Snipe Lake.

PERSIUS DUSKY WING - Erynnis persius fredericki (Freeman)

- s. Sask., n. to Deschambault Lake. GRIZZLED SKIPPER - Pyrgus centaureae freija (Warren)

- n. Sask., s. to Weekes and Flotten Lake.

SMALL CHECKERED SKIPPER - Pyrgus scriptura (Boisduval)

- Rosefield Badlands, (s.e. of Val Marie) - one male collected by

Ronald Hooper on 19 May 1983. CHECKERED SKIPPER - Pyrgus communis (Grote)

- s. Sask., n. to Punnichy, Saskatoon and Frenchman Butte.

\section{HETEROPTERINAE}

ARCTIC SKIPPER - Carterocephalus palaemon mandan (W.H. Edwards)

- n. Sask., s. to Moose Mountain Park, Fort Qu'Appelle, Punnichy and Kerrobert.

\section{HESPERIINAE}

LEAST SKIPPER - Ancyloxypha numitor (Fabricius)

- e. Sask., w. to Moose Mountain Park, Tantallon, Norquay and $\mathrm{n}$. to McBride Lake and Smoking Tent (e. of Hudson Bay).

GARITA SKIPPER - Oarisma garita (Reakirt)

- s. Sask., n. to Archerwill, Prince Albert and Pierceland. 
RHESUS SKIPPER - Yvretta rhesus (W.H. Edwards)

- Fort Qu'Appelle and Rosefield Badlands (s.e. of Val Marie).

UNCAS SKIPPER - Hesperia uncas (W.H. Edwards)

- s. Sask., n. to Round Lake (n. of Whitewood) and Sask. Landing Park.

MANITOBA SKIPPER - Hesperia comma manitoba (Scudder)

- n. Sask., s. to Pasquia Hills and Nipawin Provincial Park.

ASSINIBOIA SKIPPER - Hesperia comma assiniboia (Lyman)

- s. Sask., n. to Somme, Chelan,

Saskatoon and Battleford.

*HARPALUS SKIPPER - Hesperia comma harpalus (W.H. Edwards)

- Cypress Hills (several collected in

Cypress Hills area belong to this subspecies, according to Bill McGuire, Colorado).

PAWNEE SKIPPER - Hesperia pawnee (Dodge)

- Redvers.

PAHASKA SKIPPER - Hesperia pahaska (Leussler)

- Big Muddy Lake, Rosefield (s.e. of Val Marie).

NEVADA SKIPPER - Hesperia nevada (Scudder)

- s. Sask., n. to Wadena and Cutknife.

PECK'S SKIPPER - Polites coras (Cramer) - s. Sask., n. to Otter Rapids and Buffalo Narrows.

DRACO SKIPPER - Polites draco (W.H. Edwards)

- Cypress Hills.

TAWNY-EDGED SKIPPER - Polites themistocles (Latreille)

- s. Sask., n. to Porcupine Plain,

Prince Albert and Meadow Lake Park.

LONG DASH — Polites mystic dacotah (W.H. Edwards)

- s. Sask., n. to Bainbridge, Prince Albert and Meadow Lake Park.
DELAWARE SKIPPER - Atrytone logan (W.H. Edwards)

- s. Sask., n. to Round Lake (n. of Whitewood), Regina, Buffalo Pound Park, Saskatchewan Landing and Estuary.

*WOODLAND SKIPPER - Ochlodes sylvanoides (Boisduval)

- several collected at Val Marie by Keith Roney and Ronald Hooper on 11 August 1983.

HOBOMOK SKIPPER - Poanes hobomok (Harris)

- central Sask., n. to Bainbridge and Peerless, s. to Moose Mountain Park and Moøse Jaw.

DUN SKIPPER - Euphyes ruricola (Boisduval)

- s. Sask., n. to Deschambault Lake and La Ronge.

DUSTED SKIPPER - Artrytonopsis hianna (Scudder)

- Kamsack, Tantallon and Crooked Lake.

SIMIUS ROADSIDE SKIPPER Amblyscirtes simius (W.H. Edwards)

- Rosefield Badlands, (s.e. of Val Marie), Val Marie.

OSLAR'S ROADSIDE SKIPPER Amblyscirtes oslari (Skinner)

- Roche Percee, Val Marie and Estuary.

ROADSIDE SKIPPER - Amblyscirtes vialis (W.H. Edwards)

- s. Sask., n. to Sturgeon Landing and Otter Rapids.

\section{PAPILIONOIDEA}

PAPILIONIDAE - SWALLOWTAILS

PARNASSIINAE

* CLOUDED PARNASSIAN - Parnassius phoebus smintheus (Doubleday)

- one collected by Wayne Harris near Fort Walsh on 6 July 1982.

\section{PAPILIONINAE}

BLACK SWALLOWTAIL - Papilio polyxenes asterius (Stoll)

- Lake Alma (probably a stray) 


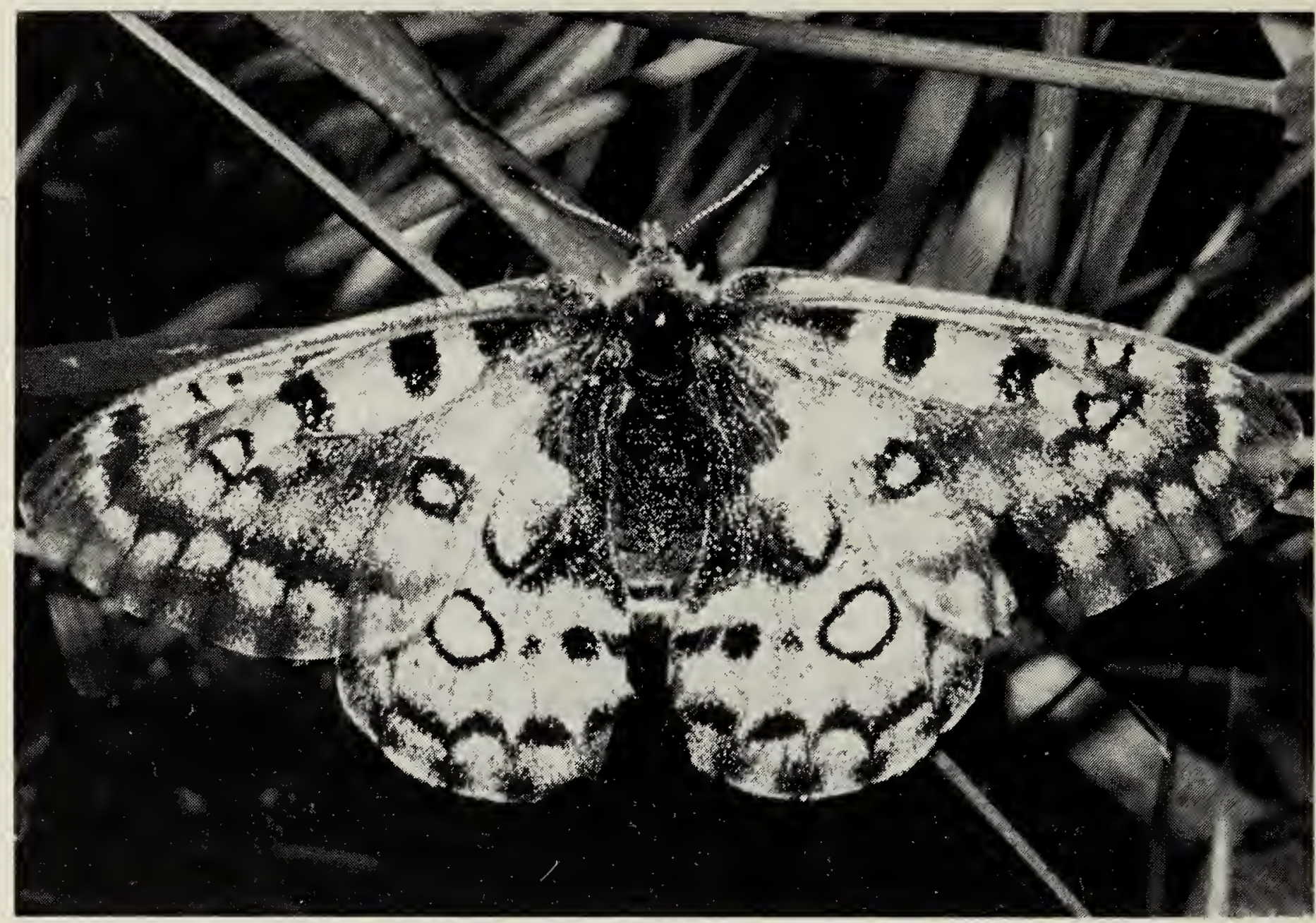

Clouded Parnassian

KAHLI SWALLOWTAIL - Papilio polyxenes kahli (F. and R. Chermock)

- e. Sask., w. to Arcola, Fort Qu'Appelle and Simpson, $\mathrm{n}$. to Somme. BADLAND OLD WORLD SWALLOWTAIL - Papilio machaon dodi (MCDunnough)

- what was called P.b. brucei, is lumped together here with $P$. $m$. dodi. True P.b. brucei occurs in Colorado.

- s. Sask., n. to Crooked Lake and Punnichy.

OLD WORLD SWALLOWTAIL - Papilio machaon hudsonianus (Clark)

- n. Sask., s. to Duck Mountain Park,

Chelan and Paddockwood.

ZELICAON SWALLOWTAIL - Papilio zelicaon (Lucas) [Gothic Swallowtail yellow form; Nitra Swallowtail - black form].

- s. Sask., n. to Punnichy and Eston. CANADIAN TIGER SWALLOWTAIL Pterourus glaucus canadensis (Rothschild and Jordan)

- throughout Sask.
C.R. Wershler

*TWO-TAILED SWALLOWTAIL - Pterourus multicaudata (Kirby)

- one taken in Cypress Hilis by $M$. Conrad on 9 August 1977; one taken near Bracken by L. Wright in July 1980; one photograph taken in June 1980 by Wayne Lynch s.e. of Val Marie along Frenchman River.

PIERIDAE - WHITES, MARBLES AND SULPHURS

\section{PIERINAE}

CHECKERED WHITE - Pontia protodice (Boisduval and Leconte)

- s. Sask., n. to Tantalion, Fort Qu'Appelle and Battleford.

WESTERN CHECKERED WHITE - Pontia occidentalis (Reakirt)

- throughout Sask.

MUSTARD WHITE - Artogeia napi oleracea (Harris)

- n. Sask., s. to Togo, Chelan, Kinistino and Harlan.

WESTERN MUSTARD WHITE - Artogeia napi marginalis (Scudder)

- Cypress Hills. 
CABBAGE WHITE - Artogeia rapae (Linnaeus)

- s. Sask., n. to Pelican Narrows, La

Ronge and La Loche.

\section{ANTHOCARINAE}

LARGE MARBLE - Euchloe ausonides mayi (F. and R. Chermock)

- central Sask., n. to Nipawin Provincial Park, s. to Togo, Eston and Cypress Hills.

* LARGE MARBLE - Euchloe ausonides palaeoreios (Johnson)

- Roche Percee area. Two specimens in American Museum of Natural History.

*CREUSA MARBLE - Euchloe creusa (Doubleday)

- Briarlee (near Shellbrook) 20 May 1976, collected by Wayne Harris; also collected by Keith Roney and Ronald Hooper at Prince Albert on 8 June 1982.

OLYMPIA MARBLE - Euchloe olympia (W.H. Edwards)

- s. Sask., n. to Regina and Dundurn.

COLIADINAE

WESTERN COMMON SULPHUR - COlias philodice eriphyle (W.H. Edwards)

- s. Sask., n. to Uranium City.

ORANGE SULPHUR - Colias eurytheme (Boisduval)

- s. Sask., n. to Sturgeon Landing,

La Ronge and Turnor Lake.

QUEEN ALEXANDRA'S SULPHUR Colias alexandra alexandra (W.H. Edwards)

- Big Muddy Lake, Killdeer Badlands, Claydon, Cypress Hills and Estuary.

CHRISTINA SULPHUR - Colias alexandra christina (W.H. Edwards)

- s. Sask., n. to Bainbridge, Prince

Albert and Frenchman Butte.

GIANT SULPHUR - Colias gigantea gigantea (Strecker)

- n. Sask., s. to Duck Mountain Park and Prince Albert.
WESTERN GIANT SULPHUR -- Colias gigantea harroweri (Klots)

- Cypress Hills.

PINK-EDGED SULPHUR - Colias interior (Scudder)

- n. Sask., s. to Somme, Chelan and Harlan.

PALAENO SULPHUR - Colias palaeno chippewa (W.H. Edwards)

- Hasbala Lake, Black Lake and Stony Rapids.

DAINTY SULPHUR - Eurema mexicana (Boisduval)

- near Round Lake (n. of Whitewood).

\section{LYCAENIDAE - GOSSAMER-WINGED BUTTERFLIES}

LYCAENINAE

AMERICAN COPPER - Lycaena phlaeas arethusa (Wolley-Dod)

- Regina.

GREAT COPPER - Gaeides xanthoides dione (Scudder)

- s. Sask., n. to Punnichy and Saskatoon.

BRONZE COPPER - Hyllolycaena hyllus (Cramer)

- s. Sask., n. to Pelican Narrows and Buffalo Narrows.

RUDDY COPPER - Chalceria rubidus (Behr)

- s.w. corner of Saskatchewan, n. to

Tompkins and Estuary.

DORCAS COPPER - Epidemia dorcas (Kirby)

- n. Sask., s. to Togo, Silver Park,

Duck Lake and Harlan.

PURPLISH COPPER - Epidemia helloides (Boisduval)

- s. Sask., n. to Bainbridge and Smoothstone Lake.

REAKIRT'S COPPER - Epidemia mariposa (Reakirt)

- Cypress Hills, central Sask., e. to Montreal Lake.

THECLINAE

CORAL HAIRSTREAK - Harkenclenus titus titus (Fabricius)

- s. Sask., n. to Moose Jaw and Tompkins. 


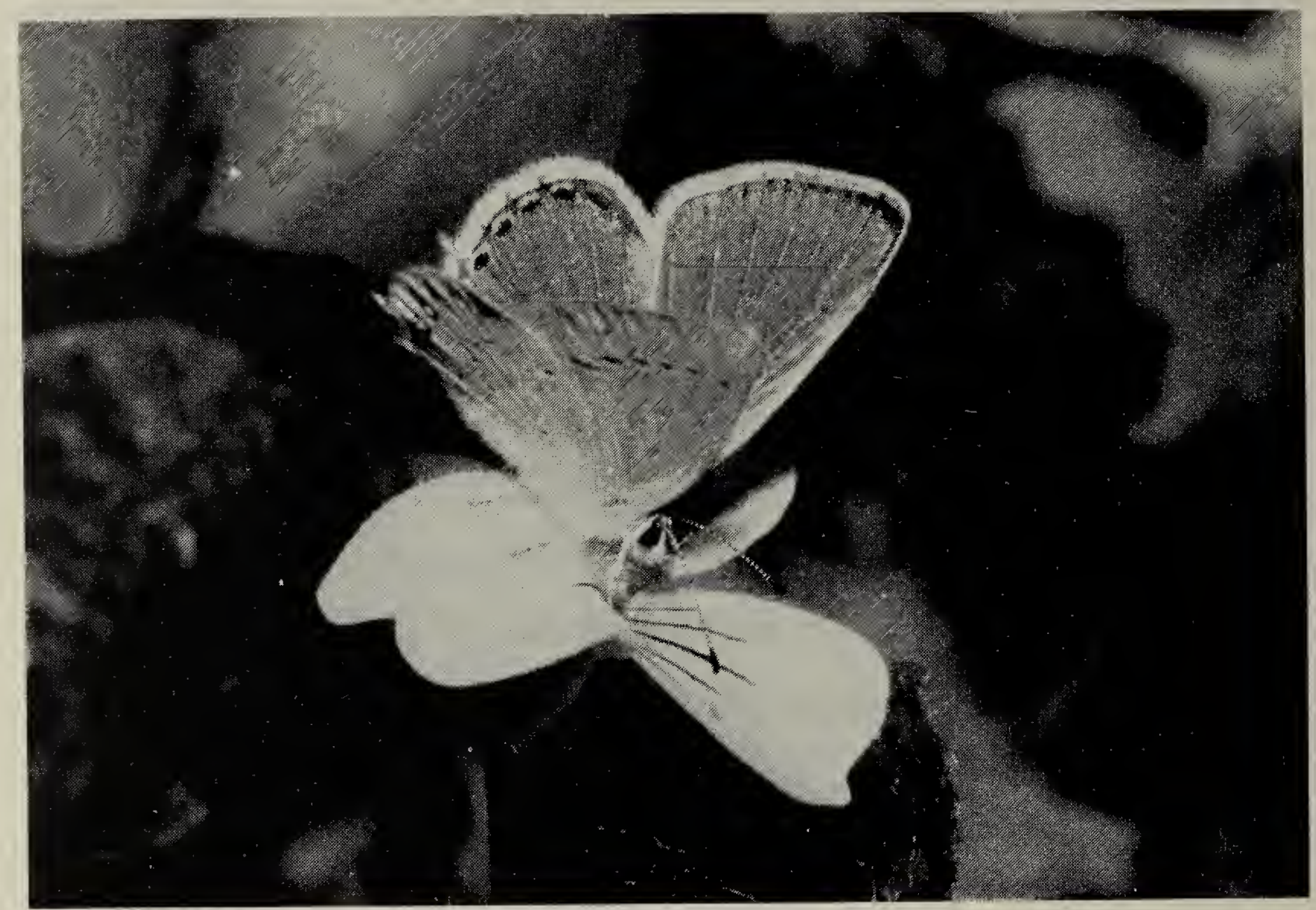

Western Tailed Blue

CORAL HAIRSTREAK - Harkenclenus titus immaculosus (Comstock)

ACADIAN HAIRSTREAK - Satyrium acadica watrini (Dufrane)

- s. Sask., n. to Wadena and Dundurn.

EDWARD'S HAIRSTREAK - Satyrium edwardsii (Grote and Robinson)

- Maryfield, Tantallon, Round Lake (n. of Whitewood).

STRIPED HAIRSTREAK - Satyrium liparops fletcheri (Michener and dos Passos)

- s. Sask., n. to Bainbridge and Nipawin.

*STRIPED HAIRSTREAK - Satyrium liparops aliparops (Michener and dos Passos)

- Killdeer Badlands.

RED-BANDED HAIRSTREAK -- Calycopis cecrops (Fabricius)

- Limerick.

JUNIPER HAIRSTREAK - Mitoura siva (W.H. Edwards)

- Rosefield badlands (s.e. of Val Marie).
C.R. Wershler

BROWN ELFIN - Incisalia augustus augustus (Kirby)

- n. Sask., s. to Preeceville, Punnichy, Duck Lake and Harlan.

*WESTERN BROWN ELFIN - Incisalia augustus iroides (Boisduval)

- Cypress Hills and Tompkins.

HOARY ELFIN - Incisalia polios obscurus (Ferris and Fisher)

- s. Sask., n. to Davin Lake and La Loche.

PINE ELFIN - Incisalia niphon clarki (Freeman)

- central Sask., s. to Chelan, Prince Albert and Loon Lake.

WESTERN PINE ELFIN - Incisalia eryphon (Boisduval)

- Cypress Hills, n. Sask., s. to Otter Rapids.

GRAY HAIRSTREAK - Strymon melinus humuli (Harris)

- s. Sask., n. to Duck Lake. 


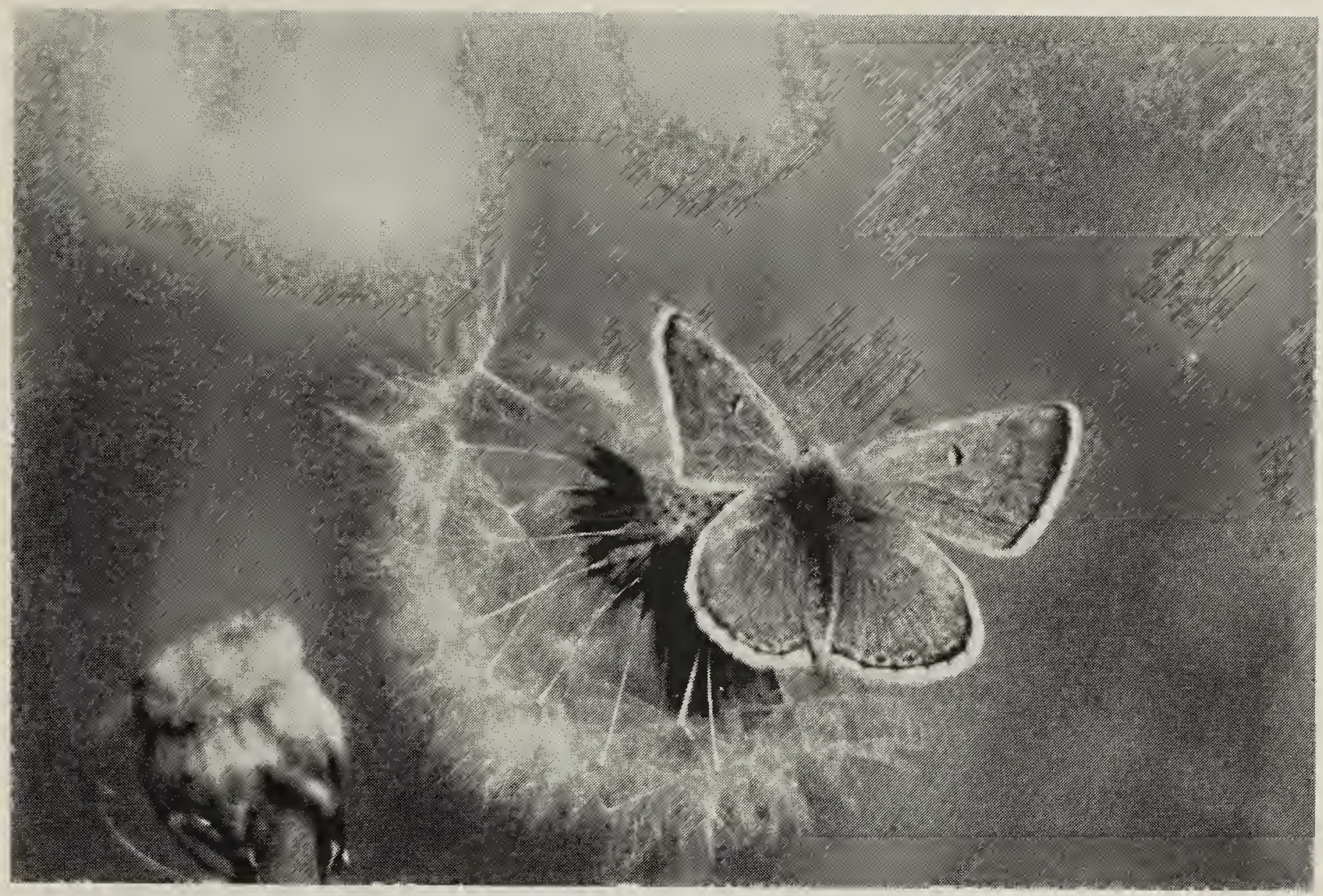

Greenish Blue

Gary Anweiler

*MARINE BLUE - Leptotes marina (Reakirt)

- one specimen taken at Glenside on 11 September 1939 by J. W. Joyce.

REAKIRT'S BLUE - Hemiargus isola (Reakirt)

- Tantallon.

WESTERN TAILED BLUE - Everes amyntula albrighti (Clench)

- s. Sask., n. to Pelican Narrows, Ot-

ter Rapids and Turnor Lake.

SPRING AZURE - Celastrina ladon lucia (Kirby)

- throughout Sask.

SPOTTED BLUE - Euphilotes enoptes ancilla (Barnes and MCDunnough)

- Rosefield Badlands (s.e. of Val Marie), Val Marie.

ARROWHEAD BLUE - Glaucopsyche piasus (Boisduval)

- Cypress Hills.
COUPER'S SILVERY BLUE - GlaUcopsyche lygdamus couperi (Grote)

- central Sask., s. to Silver Park, Prince Albert and Loon Lake.

AFRA SILVERY BLUE - Glaucopsyche lygdamus afra (W.H. Edwards)

- s. Sask., n. to Somme and Meadow Lake Park.

*ORO SILVERY BLUE - Claucopsyche lygdamus oro (Scudder)

- Cypress Hills, Val Marie and Killdeer Badlands.

SCUDDER'S BLUE - Lycaeides argyrognomon scudderi (W.H. Edwards)

- n. Sask., s. to Togo, Silver Park and Cutknife.

NORTHERN BLUE - Lycaeides argyrognomon ssp.

- s. Sask., n. to Crooked Lake and Tompkins.

MELISSA BLUE - Lycaeides melissa (W.H. Edwards)

- s. Sask., n. to Sturgeon Landing and Battleford Park. 


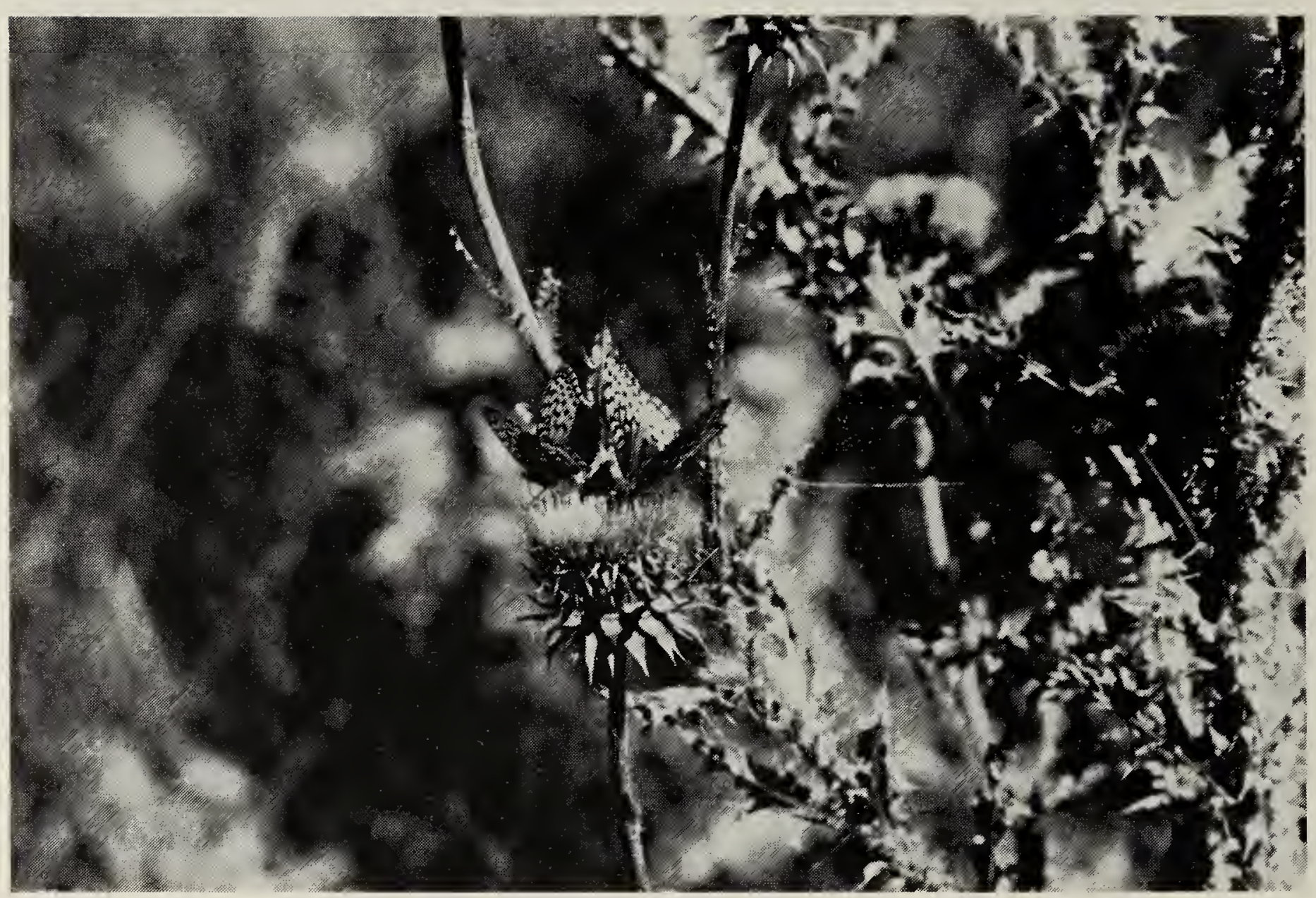

Great Spangled Fritillary (right) and Northwestern Silverspot (left)

J.B. Gollop

GREENISH BLUE - Plebejus saepiolus amica (W.H. Edwards)

- s. Sask., n. to Uranium City.

PEMBINA BLUE -- Icaricia icarioides pembina (W.H. Edwards)

- Cypress Hills, Killdeer Badlands and Rockglen.

SHASTA BLUE - Icaricia shasta minnehaha (Scudder)

- s.w. Sask., e. to Big Muddy, n. to

Sask. Landing Park, Eston and Estuary.

ACMON BLUE - Icaricia acmon lutzi (dos Passos)

- s. Sask., n. to Lebret, Regina,

Saskatchewan Landing and Eston.

YUKON BLUE - Vacciniina optilete yukona (Holland)

- n. Sask., s. to Weekes.

PRECAMBRIAN ARCTIC BLUE Agriades franklinii lacustris (Freeman)

- n. Sask., s. to Namew Lake.
PRAIRIE ARCTIC BLUE - Agriades franklinii ssp.

- formerly called rustica, but our subspecies may be distinct.

- s. Sask., n. to Bainbridge and Prince Albert.

RIODINIDAE - METALMARKS

*MORMON METALMARK - Apodemia mormo (C. and R.Felder)

- Killdeer Badlands and Val Marie.

NYMPHALIDAE - BRUSH-FOOTED

BUTTERFLIES

ARGYNNINAE

VARIEGATED FRITILLARY - Euptoieta claudia (Cramer)

- s. Sask., n. to Bainbridge, Montreal Lake and Smoothstone Lake.

GREAT SPANGLED FRITILLARY Speyeria cybele pseudocarpenteri ( $F$. and R. Chermock)

- s. Sask., n. to Bainbridge and La Ronge. 
APHRODITE - Speyeria aphodite manitoba ( $F$. and R. Chermock)

- s. Sask., n. to Bainbridge and Buffalo Narrows.

EDWARD'S FRITILLARY - Speyeria edwardsii (Reakirt)

- Oxbow, Killdeer Badlands and Cypress Hills.

ZERENE FRITILLARY - Speyeria zerene garretti (Gunder)

- Cypress Hills and Eastend.

CALLIPPE FRITILLARY - Speyeria callippe calgariana (MCDunnough)

- s. Sask., n. to Duck Lake.

ATLANTIS FRITILLARY - Speyeria atlantis hollandi (F. and R. Chermock)

- n. Sask., s. to Duck Mountain Park,

Chelan and Duck Lake.

BEAN'S FRITILLARY - Speyeria atlantis beani (Barnes and Benjamin)

- Cypress Hills.

NORTHWESTERN SILVERSPOT - Speyeria atlantis lais (W.H. Edwards)

- s. Sask., n. to Deschambault Lake

and Buffalo Narrows.

*HYDASPE FRITILLARY - Speyeria hydaspe sakuntala (Skinner)

- one taken in Cypress Hills by $M$.

Conrad on 9 August 1977. MORMONIA FRITILLARY - Speyeria mormonia eurynome (W.H. Edwards)

- s. Sask., n. to Somme and Prince Albert.

BOG FRITILLARY - Proclossiana eunomia dawsoni (Barnes and McDunnough)

- n. Sask., s. to Togo, Chelan and Harlan.

SILVER-BORDERED FRITILLARY - Clossiana selene atrocostalis (Huard)

- throughout Sask.

MEADOW FRITILLARY - Clossiana bellona jenistae (Stallings and Turner)

- throughout Sask.

FRIGGA FRITILLARY - Clossiana frigga saga (Staudinger)

- n. Sask., s. to Togo and Raymore. FREIJA FRITILLARY - Clossiana freija (Thunberg)

- n. Sask., s. to Togo, Prince Albert and Harlan, and also Cypress Hills and Besant (1 stray).
*BOISDUVAL'S FRITILLARY - Clossiana titania boisduvalii (Duponchel)

- Hasbala Lake, Patterson Lake and Johnson River.

PURPLE LESSER FRITILLARY - Clossiana titania grandis (Barnes and MCDunnough) - n. Sask., s. to Somme, Duck Lake and Harlan; also in Cypress Hills and Val Marie (1 stray).

\section{MELITAEINAE}

CARLOTA CHECKERSPOT - Charidryas gorgone carlota (Reakirt)

- s. Sask., n. to Archerwill and Peerless.

HARRIS' CHECKERSPOT - Charidryas harrisii hanhami (Fletcher)

- Tantallon and Arran.

NORTHERN CHECKERSPOT - Charidryas palla (Boisduval)

- Roche Percee.

*ACASTUS CHECKERSPOT — Charidryas acastus (W.H. Edwards)

- s. Sask., n. to Claybank, Sask. Landing Park.

SOUTHERN PEARL CRESCENT Phyciodes tharos (Drury)

- s. Sask., n. to Yorkton, Punnichy and Tramping Lake Park.

NORTHERN PEARL CRESCENT Phyciodes pascoensis (Wright)

- Opler and Krizek (1984) list pascoensis as a separate and distinct species from tharos.

- n. Sask., s. to Moose Mountain Park, Pike Lake and Kerrobert; also in Wood Mountain and Cypress Hills.

MEADOW CRESCENT - Phyciodes pratensis pratensis (Behr)

- Cypress Hills and Cutknife.

TAWNY CRESCENT — Phyciodes pratensis batesii (Reakirt)

- placed here as there is evidence of $P$. batesii and $P$. pratensis hybridizing in Cypress Hills. Ferris and Brown also suggest they may be interbreeding.'

- throughout Sask.

HEWITSON'S CHECKERSPOT - Occidryas anicia (Doubleday and Hewitson)

- Cypress Hills. 
EDITH'S CHECKERSPOT - Occidryas editha hutchinsi (MCDunnough)

- Cypress Hills.

NYMPHALINAE

QUESTION MARK - Polygonia interrogationis (Fabricius)

- Indian Head.

HOP MERCHANT - Polygonia comma (Harris)

- Glen Ewen and Roche Percee.

SATYR ANGLE WING - Polygonia satyrus (W.H. Edwards)

- s. Sask., n. to Otter Rapids.

GRAY COMMA - Polygonia progne progne (Cramer)

- s. Sask., n. to Otter Rapids.

HOARY COMMA - Polygonia gracilis gracilis (Grote and Robinson)

- n. Sask., s. to Candle Lake and Meadow Lake Park.

ZEPHYR ANGLE WING - Polygonia gracilis zephyrus (W.H. Edwards)

- Cypress Hills.

GREEN COMMA - Polygonia faunus rusticus (W.H. Edwards)

- n. Sask., s., to Duck Mountain Park and Dundurn; also in Cypress Hills. COMPTON TORTOISE SHELL - Nymphalis vau-album watsoni (Hall)

- this western ssp. is listed by Ferris and Brown.' central Sask., s. to Moose Mountain Park, Fort Qu'Apvelle and Duck Lake.

CALIFORNIA TORTOISE SHELL - Nymphalis californica herri (Field)

- Somme, Indian Head, Saskatoon and Brock.

MOURNING CLOAK - Nymphalis antiopa antiopa (Linnaeus)

- throughout Sask.

MILBERT'S TORTOISE SHELL - Aglais milberti (Godart)

- throughout Sask.

AMERICAN PAINTED LADY - Vanessa virginiensis (Drury)

- Welby, Indian Head, Wadena, Hudson Bay.

PAINTED LADY - Vanessa cardui (Linnaeus)

- throughout Sask.
WESTERN PAINTED LADY - Vanessa annabella (Field)

- Indian Head and Cypress Hills.

RED ADMIRAL - Vanessa atalanta (Linnaeus)

- s. Sask., n. to La Ronge and Buffalo Narrows.

LIMENITIDINAE

WHITE ADMIRAL - Basilarchia arthemis rubrofasciata (Barnes and McDunnough) - throughout Sask.

VICEROY - Basilarchia archippus (Cramer)

- throughout Sask.

\section{SATYRIDAE - MEADOW BROWNS ELYMNIINAE}

NORTHERN PEARLY EYE - Enodia anthedon (Clark)

- e. Sask., w. to Trossachs, Punnichy and Meadow Lake Provincial Park. EYED BROWN - Satyrodes eurydice (Johansson)

- Gainsborough, and Smoking Tent (e. of Hudson Bay).

\section{SATYRINAE}

LITTLE WOOD SATYR - Megisto cymela (Cramer)

- Maryfield, Tantallon and Round Lake (n. of Whitewood).

RINGLET - Coenonympha inornata (W.H. Edwards)

- s. Sask., n. to Bainbridge, Nipawin and Meadow Lake Park.

COMMON WOOD NYMPH - Cercyonis pegala ino (Hall)

- s. Sask., n. to Bainbridge, Green

Lake and Meadow Lake Park.

SMALL WOOD NYMPH - Cercyonis oetus (Boisduval)

- S.w. Sask., e. to Killdeer Badlands,

n. to Chaplin, Saskatchewan Landing and Estuary.

MANCINUS ALPINE - Erebia disa mancinus (Doubleday and Hewitson)

- n. Sask., s. to Somme, Prince Albert and Harlan; also in Cypress Hills. 


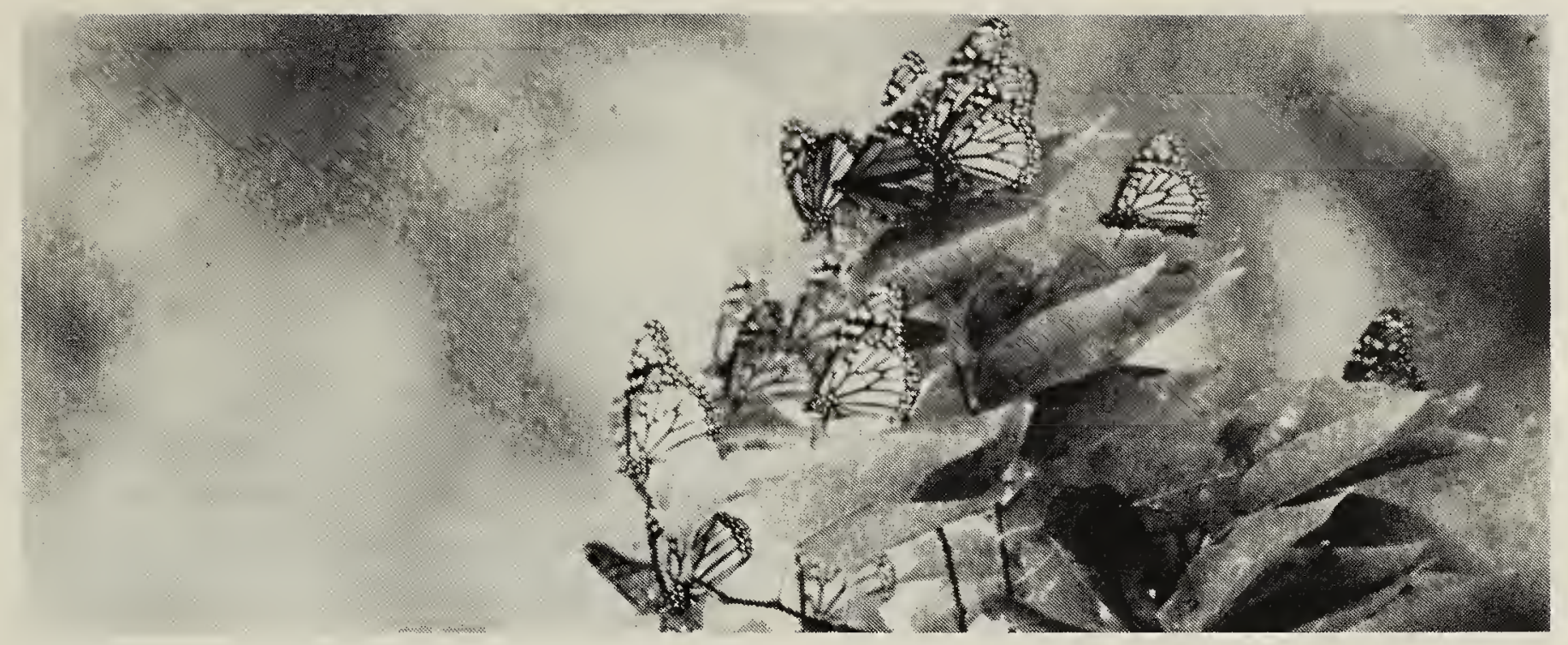

Monarch Butterflies

Juhachi Asai

RED-DISKED ALPINE - Erebia discoidalis (Kirby)

- n. Sask., s. to Maryfield, Fort

Qu'Appelle and Dundurn.

COMMON ALPINE - Erebia epipsodea freemani (Ehrlich)

- s. Sask., n. to Somme, Prince

Albert and Peerless.

RIDING SATYR - Neominois ridingsii (W.H. Edwards)

- s. Sask., n. to Shellbrook.

MACOUN'S ARCTIC - Oeneis macounii

(W.H. Edwards)

- central Sask., s. to Duck Mountain

Park, Duck Lake and Harlan, n. to Lynx Lake.

CARY'S ARCTIC - Oeneis chryxus caryi (Dyar)

- central Sask., e. to Prince Albert, n. to Lloyd Lake

VARUNA ARCTIC - Oeneis uhleri varuna (W.H. Edwards)

- s. Sask., n. to Leross, Saskatoon and Turtleford.

ALBERTA ARCTIC - Oeneis alberta (Elwes)

- s. Sask., n. to Punnichy and Batoche.

JUTTA ARCTIC - Oeneis jutta ridingiana ( $F$. and R. Chermock)

- n. Sask., s. to Duck Mountain Park, Chelan, and Harlan; also Cypress Hills(?).
DANAIDAE - MONARCHS

MONARCH - Danaus plexippus (Linnaeus)

- s. Sask., n. to Creighton.

1 FERRIS, C.D., and F.M. BROWN. 1981. Butterflies of the Rocky Mountain States. University of Oklahoma Press, Norman, Oklahoma.

2 HOOPER, R.R. 1969. A preliminary list of the butterflies of Saskatchewan. Midcontinent Lepidoptera Series 1(5).

3 HOOPER, R.R. 1973. Butterflies of Saskatchewan. Sask. Museum of Natural History, Regina. 216 pp.

${ }^{4}$ MILLER, L.D. and F. M. BROWN. 1981. A catalogue/checklist of the butterflies of America north of Mexico. Lep. Soc. Mem. 2.

5 OPLER, P.A., and G.O. KRIZEK. 1984. Butterflies east of the Great Plains. Johns Hopkins University Press, Baltimore and London.

6 SCOTT, J.A. 1984. A review of Polygonia progne (oreas) and $P$. gracilis (zephyrus) (Nymphalidae), including a new subspecies from the southern Rocky Mountains. J. Res. Lepid. 23(3):197-210.

7 SPFRLING, F.A.H. 1986. Evolution of the Papilio machaon species group in western Canada (Lepidoptera: Papilionidae). M Sc. thesis. University of Alberta, Edmonton. 